\title{
The Socio-Demographic Factors and Unspeakable Impacts of Street Harassment towards Young Malaysian Women's Mental Health
}

\section{Latifah Binti Abd Latib, Nor Zakiah Binti Ismail, Munirah Binti llias}

To Link this Article: http://dx.doi.org/10.6007/IJARBSS/v11-i19/11744 DOI:10.6007/IJARBSS/v11-i19/11744

Received: 19 October 2021, Revised: 23 November 2021, Accepted: 11 December 2021

Published Online: 22 December 2021

In-Text Citation: (Latib et al., 2021)

To Cite this Article: Latib, L. B. A., Ismail, N. Z. B., \& Ilias, M. B. (2021). The Socio-Demographic Factors and Unspeakable Impacts of Street Harassment towards Young Malaysian Women's Mental Health. International Journal of Academic Research in Business and Social Sciences, 11(19), 404-416.

\section{Copyright: @ 2021 The Author(s)}

Published by Human Resource Management Academic Research Society (www.hrmars.com)

This article is published under the Creative Commons Attribution (CC BY 4.0) license. Anyone may reproduce, distribute, translate and create derivative works of this article (for both commercial and non-commercial purposes), subject to full attribution to the original publication and authors. The full terms of this license may be seen at: http://creativecommons.org/licences/by/4.0/legalcode

Special Issue Title: Youth and Community Wellness, 2021, Pg. 404 - 416 


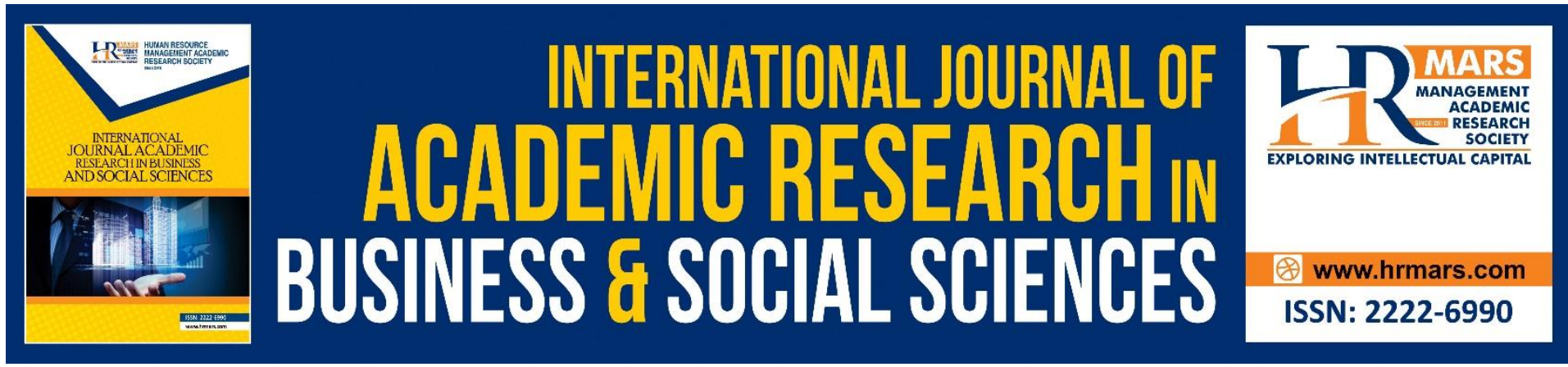

\title{
The Socio-Demographic Factors and Unspeakable Impacts of Street Harassment towards Young Malaysian Women's Mental Health
}

\author{
Latifah Binti Abd Latib ${ }^{1,2}$ \& Nor Zakiah Binti Ismail ${ }^{2}$, Munirah \\ Binti llias ${ }^{2}$ \\ ${ }^{1}$ Institute for Social Science Studies, Universiti Putra Malaysia, 43400 Serdang Selangor, \\ Malaysia, ${ }^{2}$ Faculty of Communication, Visual Art and Computing, Universiti Selangor, Jalan \\ Timur Tambahan, 45600 Bestari Jaya, Selangor, Malaysia. \\ Corresponding Author Email: latifah@unisel.edu.my
}

\begin{abstract}
Recently, women have been subjected to sexual harassment and assault daily, which has left them in a quandary about whether or not they should tell trusted individuals about it. Unfortunately, most common forms of sexual harassment, such as street harassment, are disregarded and considered a biological fact of life that women must endure. Therefore, a quantitative survey involving 385 women has been conducted to explore the sociodemographic factors towards the impacts of street harassment on young Malaysian women's mental health. The analysis highlighted that the majority of the young women had experienced street harassment such as catcalling, wolf-whistling or sexual comments. In addition, socio-demographic factors such as age group and race group have different impacts on young Malaysian women's mental health caused by street harassment. In conclusion, by analyzing the socio-demographic factors, the government and organizations will benefit from effective action to prevent street harassment among young Malaysians.
\end{abstract}

Keywords: Street Harassment, Young Women, Mental Health, Catcalling, Wolf-whistling

\section{Introduction}

Sexual harassment is a big crime that affects many women and men. It is one of the most serious challenges facing women and girls everywhere. In Malaysia, sexual harassment is one of the concerns that young Malaysian women are exploring. As reported by Women's Aid, 39 per cent have experienced offensive sexual jokes or innuendos, $24 \%$ have had unwanted touching or grabbing, $22 \%$ have experienced sexual gestures, body movements, or looks, $18 \%$ have experienced stalking behaviour, and $16 \%$ have experienced verbal sexual abuse (Dandavati, 2020). A survey conducted by ENGENDER Consultancy and Sisterhood Alliance revealed that 60.25 per cent of Malaysian respondents had experienced sexual harassment in public areas (Dandavati, 2020). Street harassment, also known as "eve-teasing," is another form of sexual harassment common in this part of the world but is rarely discussed. This sexual harassment situation specifically refers to harassment experienced by women in public 
spaces such as streets, parks, modes of public transportation, and bus stops from men who are strangers (Dhillon \& Bakaya, 2014).

Fairchild and Rudmanas (as cited in Dhillon \& Bakaya, 2014) stated that street harassment shares many common themes with sexual harassment that occurs in other contexts. When a man, through words, signs, and/or visible representation or gesture, performs any act in public space, or signs, recites, or utters any offensive words, song, or ballad in any public place to the annoyance of any woman, referred to the actions of street harassment. Street harassment is also defined as any kind of unwanted whistling, leering, sexist, homophobic, or transphobic slurs, persistent requests for someone's name, number, or destination after they have said no, sexual names, comments, and demands, following, flashing, public masturbation, groping sexual assault, and rape (Stop Street Harassment.org, 2015).

Street harassment is a human rights issue because it restricts harassed people's ability to be in public, particularly women. Many women experience sexual harassment on a daily basis that is not reported anywhere due to insecure feelings. Despite its serious implications for women's quality of life and psychological well-being, street harassment is an area that has received little attention in Malaysia. Therefore, this paper will attempt to identify the street harassment experienced by young women. These socio-demographic predictor factors are age, race, employment status and location. Via the specific information on the type of street harassment and socio-demographic factors, it will give insight into the mental health impact of street harassment and guidance in managing effective action and strategies to prevent street harassment among women.

\section{Literature Review}

\section{Global Street Harassment Issues}

A new survey conducted by L'Oréal Paris in collaboration with Ipsos (2021) found that street harassment persists despite the Covid-19 crisis, which has drastically reduced the number of people in public spaces through lockdowns and curfews. In the midst of the pandemic, more than four out of ten women (41\%) say they feel less safe in public places, and 47 per cent say masks, which allow people to hide their faces, have contributed to their fear. Furthermore, the fact that there are fewer people on the streets and public transportation appears to have a negative impact on more than half of women under the age of 35 's perceptions of safety.

Kearl (as cited in Dhillon and Bakaya, 2014) stated that women in the United Kingdom and Egypt had reported similar forms of harassment. Regarding the types of public spaces where such harassment was most common, rather than isolated locations where a woman might find herself alone with the harasser, harassment was reported to occur in crowded spaces. Although it may be perceived that women are safer in places where other people surround them, this does not appear to be the case when it comes to street harassment.

Previous research on street harassment has been conducted to explore the experience of young women in Delhi. Interviews were conducted with 20 women between the ages of 18 and 30 to learn about the types of harassment they experienced, the perceived consequences, how they coped with it. The changes they felt were required for them to feel safer. According to the findings, harassment occurs most frequently in crowded areas and broad daylight. High levels of harassment have been attributed to prevalent attitudes toward 
women and lax enforcement of laws. The harassment hampered the participants' lives in a variety of ways. Because the police were perceived to be apathetic, women took on the responsibility of keeping themselves safe. Due to the risk of escalation, women may choose to defend themselves by moving away from harassers rather than confronting them. Several participants, however, felt that remaining silent allowed harassment to continue. The main change that women desired was more effective police operations (Dhillon and Bakaya, 2014).

Whereas, in Egypt, sexual harassment (SH) is one of the major issues. Egypt leads the Arab World in SH. According to the Arab Barometer's fifth wave, 42 per cent reported some verbal harassment, and 29 per cent reported some physical harassment across genders over 12 months. The problem is especially acute for women, with 63 per cent of women reporting some form of SH within a year - and nearly all younger women reporting some form of harassment (90 percent of women aged 18-29, and 88 percent of women aged 30-39). The findings of a Thomson Reuters survey revealed that out of the world's 19 largest megacities, Cairo is the most dangerous city for women overall and the third most dangerous for sexual violence. A nationally representative survey shows that nearly $40 \%$ of young women aged 13 to 35 reported SH in 2014, with 60\% living in informal urban areas (Ismail, Abdel-Tawab and Sheira, 2015). Finally, a government study found that more than 1.7 million women were exposed to various forms of $\mathrm{SH}$ in public transportation, 2.5 million were exposed to $\mathrm{SH}$ on the streets within a year, and 16,000 women aged 18 or older were exposed to $\mathrm{SH}$ at educational institutions within a year, costing the Egyptian state 571 million Egyptian pounds per year. Given these statistics, it is critical to investigate current policies for preventing SH against women and propose some potential solutions for creating safe public spaces for women in Egypt (Arab Barometer.org, 2020). As conclusion, the sexual harassment occurs most frequently in crowded and public areas and broad daylight. This type of sexual harassment situation is called street harassment.

\section{Types of Street Harassment}

Street harassment is the beginning of the sexual harassment where this mildly stresses one's mental health and end up in physical assault. As stated by Fairchild and Rudman (as cited in Dhillon \& Bakaya, 2014), street and sexual harassment were likely similar that varies in different actions with unwanted sexual behavior. Street harassment is also defined as the situation where women experienced the intrusion among men in the public space (Vera-Gray, 2016). Street harassment happened in many countries and this issue has been discussed and explored in many studies in different countries. The study conducted at U.S. Northeastern university highlighted the issue of street harassment and the psychological impacts such as anxiety, depression and sleep quality among women (DelGreco \& Christensen, 2020).

Another study conducted in New York City also addressed the issue of street harassment among women and it has affected women to unhealthy states of mind and emotion such as feeling unsafe, blaming themselves, and questioning the legitimacy of the encounter (Farmer \& Smock Jordan, 2017). It is also reported that the statistic of women involved in the sexual harassment cases is quiet high in three years back since 2015 until 2017 based on the cases reported to Royal Malaysia Police (PDRM) in Malaysia (Sexual Harassment Statistics in Malaysia - Women's Aid Organisation, n.d.). Most of the sexual harassment cases reported were the cases that happened in public space. Thus, Malaysia is not an exception and Malaysian women are at stake of being the victims of street harassment. It is clearly 
understood, street harassment is a crucial issue among women including Malaysian women. There are many terms used to reflect street harassment. Catcalling is one type of street harassment (Farmer \& Jordan, 2017).

According to Logan (as cited by Fileborn \& Vera-Gray, 2017) street harassments consisted of catcalling, wolf-whistling, prolonged staring or ogling, groping, following someone or stalking, and intrusive verbal comments typically included within definitions. Understanding each of the street harassment types is one of the precautions that people can take to avoid becoming one of the victims of street harassment. Among the types of street harassment addressed in the previous studies is staring. According to Berger (as cited in Renwick, et al., 2016) and Roenius (as cited in Betts et al., 2019), staring is the action of deep communication of intense, meaningful motive and a form of dehumanizing behavior. This typically involved social interaction between both parties of the individual who starred and the individual who received the stars. Westrup \& Fremouw (1998) explained that stalking is an unwelcomed behavior which is done repeatedly and continuous harassing or threatening behavior directed towards an individual. The actions like showing up at a person's place when you did not want them to be there, watching or following a person from a distance and leaving a person card or letters that they knew the person did not want are among the actions that are associated with stalking (Chung, 2020).

Other than that, wolf whistling is another type of street harassment. Violence is always not physical based but the serious sexual harassment women faces, normally starts from the minor wolf-whistle. Wolf whistling is a street harassment which is not perceived as harmless but it depends on the level of acceptance of women. Some of the women take wolf whistling as a compliment that reflects on their good looks but some of the women might find it rude and it is like a threat because it showed that men did not respect them and put them in fear (Gavin \& Mp, 2018). Sexual suggestive attitudes or behaviors are also one of the street harassment types. It may happen to women when they are in public settings. The action of men showing their private parts, doing public masturbation or exposing any part of their body that might not be comfortable and appropriate to women in public were among the actions associated with sexual suggestive attitudes (Gavin \& Mp, 2018). The type of street harassment that is mostly faced by women is sexual comments. Sexual comments are likewise unwelcome statements relating to a person's sex. It can affect the emotional well-being of the victims and lead to bullying incidents and it is also proven that the majority of victims are among the females (Penfield, 2017). It can be concluded that among the types of street harassment that women have been facing are staring, wolf-whistling, stalking, sexually suggestive attitudes and sexual comments.

\section{Impacts of Street Harassment}

Nowadys, women could feel unsafe and anxious through their everyday lives, running or walking around the streets. They are afraid of being harassed by men, resulting in short- or long-term impacts on mental health. Among the impacts of street harassment are anxiety, depression, and poor sleep quality (DelGreco \& Christensen, 2020). It is supported by Davidson et al., (2016) that street harassment had led to anxiety among women, especially when they are in an isolated public setting, and that affected their perception of no longer being safe in a public setting as a whole. Other than that, women facing the impacts of street harassment implied a few other conditions, such as feeling unsafe, blaming themselves, and questioning the legitimacy of the encounter (Farmer \& Smock Jordan, 2017). The victims of street harassment are varied in age. They can be among teenagers, young adults and working 
adults. The impact of street harassment on mental health is considered mild compared to young adults and working adults. Street harassment may affect teenagers mentally and emotionally, such as negative self-esteem and depression (Safe Routes to School National Partnership, 2017). Young adults and working women may strongly impact their mental health when they experience street harassment. They may lose their freedom to enjoy their life in public and can negatively affect feelings of safety, bodily autonomy and mental health (Gavin \& Mp, 2018).

Focusing on the impacts of street harassment on women's mental health, the severity of street harassment resulting in different mental health conditions. According to Tiffanie Heben (as cited by Stop Street Harassment, 2015), there are three levels of street harassment severity; severe, moderately severe and least severe. Severe street harassment includes suggestive comments in reference to a woman's body or to sexual activities, obscenity that are directed at a woman because of her gender, any comment that fits into these categories combined with racial or ethnic slurs, any comment that reflects any of these three categories about a woman's possible homosexuality, and physical acts such as stalking a woman, throwing things at her, or pinching or poking her.

On the other hand, moderately severe street harassment includes sexual slurs and references to a woman's sex or body that is not sexually explicit. The third level of street harassment is least severe, which includes staring, whistling, and all other comments men make to women that women did not welcome. Thus, the most and the least severity of street harassment may influence the mental state of women of which condition of mental health they are facing; anxiety, depression, self-blaming, low or negative self-esteem and dependent behaviour. Street harassment affected different people differently based on what they had been experiencing, and it created vulnerability to psychological disorders (Safe Routes to School National Partnership, 2017). Therefore, this study has been conducted to identify the experience level of street harassment among young Malaysian women and also to investigate whether the socio-demographic factors will have different impacts on Malaysian young women due to street harassment.

\section{Research Methodology and Instrument}

The researcher used a descriptive design for the study and using a purposive sampling technique. A sample size of $\mathbf{3 8 5}$ was calculated using a Raosoft sample size calculator and the questionnaires were distributed to Klang Valley women youths. Selangor has been chosen in this survey since Klang Valley has been the highest sexual harassment rate (WAO, 2017). Klang Valley is divided into three areas which are city, town and suburban. Data were collected through survey instruments to explore each socio-demographic factor towards mental health impact on young women. A set of the questionnaire consisted of three sections which are user profile (4 items), Street Harassment Type ( 8 items), Mental Health Impact (14 items) were asked to respondents to rate their opinion using a 4-point scale (1=Strongly disagree, 2=Disagree, 3=Agree and 4=Strongly agree).

Cronbach's Alpha, a frequently used measure of internal consistency (reliability) linked with scores generated from a scale, was employed in this investigation. The Alpha Cronbach values for Street Harassment Experience (0.78) and Mental Health Impact (0.90) were found in the pre-testing (0.89). As a result, the items accurately measure the intended structures and 
variables. Analyses of Variance (ANOVA) were performed to see if socio-demographic factors differed significantly across various groups. The key data obtained for the study were tested, and the results are listed below the fold.

\section{Result and Discussion}

Demographic

Table 1: Respondents Demographic Characteristics ( $\mathrm{N}=385$ )

\begin{tabular}{lrr}
\hline Demographics & Frequency & Percentage (\%) \\
\hline Age & & \\
$18-21$ & 99 & 25.7 \\
$22-25$ & 196 & 50.9 \\
$26-30$ & 90 & 23.4 \\
& & \\
\hline Employment Status & & \\
Student & 162 & 42.1 \\
Employed & 170 & 44.2 \\
Unemployed & 53 & 13.8 \\
& & \\
\hline Race & & \\
Malay & 107 & 27.8 \\
Chinese & 81 & 21.0 \\
Indian & 183 & 47.5 \\
Others & 14 & \\
& & \\
\hline Location & 183 & 21.6 \\
City & & 47.5 \\
Town & & \\
Sub-urban & & \\
& & \\
\hline
\end{tabular}

\section{Street Harassment Experience}

Based on Table 2, the overall mean for street harassment experience is more than 3.5, showing that the majority of the young women had experienced street harassment in their life. The highest mean shows that they have experienced wolf-whistling on the street with the mean of 4.00 , followed by the top three highest means which were experienced catcalling on the street with the mean of 3.90, encountered continuous stares from unknown people on streets with a mean of 3.85 and have experienced sexual comments while walking on streets with a mean of 3.83 . 
Table 2: Street Harassment Experience

\begin{tabular}{|c|c|c|c|c|c|c|}
\hline \multirow{2}{*}{$\begin{array}{l}\text { Street Harassment Experience } \\
\text { (Overall mean: 3.85, S.D: } 1.02 \text { ) }\end{array}$} & \multicolumn{4}{|c|}{$\%$ of frequency } & \multirow[t]{2}{*}{ M } & \multirow[t]{2}{*}{ S.D } \\
\hline & 1 & 2 & 3 & 4 & & \\
\hline I have experienced wolf-whistling on street & 0.3 & 1.8 & 6.0 & 92.0 & 4.00 & 2.08 \\
\hline I have experienced cat-calling on street & 0.0 & 0.0 & 10.4 & 89.6 & 3.90 & 0.31 \\
\hline $\begin{array}{l}\text { I have encountered continuous stares from } \\
\text { unknown people on streets }\end{array}$ & 0.0 & 9 & 9.9 & 87.8 & 3.85 & 0.41 \\
\hline $\begin{array}{l}\text { I have experienced unknown people } \\
\text { stalking me on streets }\end{array}$ & 0.3 & 6.8 & 9.6 & 83.4 & 3.76 & 0.58 \\
\hline $\begin{array}{l}\text { I have experienced sexual comments while } \\
\text { walking on streets }\end{array}$ & 1.3 & 7.5 & 8.8 & 82.4 & 3.83 & 2.16 \\
\hline $\begin{array}{l}\text { I have experienced sexual suggestive } \\
\text { attitude from people on streets }\end{array}$ & 1.3 & 6.5 & 9.6 & 82.6 & 3.76 & 0.58 \\
\hline
\end{tabular}

\section{Mental Health Experience}

Based on Table 3, the overall mean for mental health experience is more than 3.5, showing that the majority of the young women had experienced mental health in their life. It shows that the majority of young women often self-objectify themselves due to street harassment. Besides that, young women also faced anxiety problems, low self-esteem and acquired dependent behaviors due to street harassment. 
Table 3: Mental Health Experience

\begin{tabular}{|c|c|c|c|c|c|c|}
\hline \multirow{2}{*}{$\begin{array}{l}\text { Mental Health Experience } \\
\text { (Overall mean: } 3.83, \text { S.D: } 0.47 \text { ) }\end{array}$} & \multicolumn{4}{|c|}{$\%$ of frequency } & \multirow[t]{2}{*}{$M$} & \multirow[t]{2}{*}{ S.D } \\
\hline & 1 & 2 & 3 & 4 & & \\
\hline $\begin{array}{l}\text { Victims often self-objectify themselves due } \\
\text { to street harassment }\end{array}$ & 0.3 & 2.8 & 9.2 & 86.4 & 3.84 & 0.46 \\
\hline $\begin{array}{l}\text { Victims often faces anxiety problem due to } \\
\text { street harassment }\end{array}$ & 0.5 & 3.3 & 8.7 & 86.2 & 3.83 & 0.50 \\
\hline $\begin{array}{l}\text { Victims often acquire low self-esteem from } \\
\text { street harassment }\end{array}$ & 0.8 & 3.1 & 9.2 & 85.6 & 3.82 & 0.51 \\
\hline $\begin{array}{l}\text { Victims often acquire dependent behaviors } \\
\text { from street harassment }\end{array}$ & 0.8 & 2.6 & 10.1 & 86.5 & 3.82 & 0.50 \\
\hline $\begin{array}{l}\text { Victims often faces depression from } \\
\text { continuous street harassment }\end{array}$ & 0.8 & 3.3 & 10.5 & 84.1 & 3.80 & 0.52 \\
\hline
\end{tabular}

Table 4 shows the result of ANOVA between the age groups and the mental health impact of the respondents. An analysis of the significance of the age group difference was done using Tukey's post-hoc test. The results revealed a significant difference between age group and mental health impact $(p<0.05)$. In addition, the results revealed that respondents' age group 26-30 years old showed a much higher impact on mental health such as anxiety, depression, self-blaming, low or negative self-esteem relative to the other age groups.

Table 4: Age Group Factor

\begin{tabular}{lllllllll}
\hline Characteristic & Factor & \multicolumn{3}{c}{ Categories } & & F value & $p$-Value \\
& & & & $18-21$ & $22-25$ & $26-30$ & & \\
& & $N$ & 99 & 196 & 90 & 3.68 & $.026^{*}$ \\
\multirow{2}{*}{ Impact Mental Health } & Age group & Mean & 31.03 & 30.21 & 31.19 & & \\
& & & S.D. & 2.72 & 3.82 & 2.28 & & \\
\hline
\end{tabular}

Post hoc test

$\begin{array}{llll}(I) \text { Age } & (J) \text { Age } & \text { Mean difference }(I-J) & \text { Sig. } \\ 26-30 & 18-21 & .16 & .940 \\ & 22-25 & .97 & .049 * *\end{array}$

$* p \leq 0.05$.

** The mean difference is significant at the .05 level. 
Table 4 shows the result of ANOVA between the race group and the mental health impact of the respondents. The analysis using Tukey's post-hoc test showed a significant difference between race group and mental health impact $(p<0.05)$. In addition, the results revealed that respondents' race who were Chinese group had the highest mean score and showed a much higher impact on their mental health than other races (Malay and Indian).

Table 5: Race Group Factor

\begin{tabular}{|c|c|c|c|c|c|c|c|c|}
\hline \multirow[t]{3}{*}{ Characteristic } & \multicolumn{2}{|c|}{ Factor } & \multicolumn{3}{|c|}{ Categories } & & \multirow[t]{2}{*}{$F$ value } & \multirow[t]{2}{*}{$p$-Value } \\
\hline & & & Malay & Chinese & Indian & Others & & \\
\hline & & $N$ & 107 & 81 & 183 & 14 & 6.96 & $.000^{*}$ \\
\hline \multirow{2}{*}{$\begin{array}{l}\text { Impact } \\
\text { Mental } \\
\text { Health }\end{array}$} & Race & Mean & 29.07 & 31.74 & 30.63 & 31.86 & & \\
\hline & & S.D. & 4.11 & 1.10 & 3.32 & 0.36 & & \\
\hline
\end{tabular}

\section{Post hoc test}

$\begin{array}{llll}(I) \text { Race } & (J) \text { Age } & \text { Mean difference }(I-J) & \text { Sig. } \\ \text { Chinese } & \text { Malay } & 2.04 & .000^{* *} \\ & 1.11 & .048^{* *} \\ & \text { Indian } & -.12 & .999\end{array}$

${ }^{*} p \leq 0.05$.

**The mean difference is significant at the .05 level.

Table 5 shows the result of ANOVA between the employee groups and the mental health impact of the respondents. An analysis of the significance of the age group difference was done using Tukey's post-hoc test. However, the analysis revealed no significant difference between the employment group and mental health impact ( $p>0.05)$. It shows that whether they are students, working at the office or homemakers, their mental health impact caused by street harassment was equally same. Furthermore, all women will faced the same impact of street harassment even though they have different job descriptions. 
Table 6: Employment Group Factor

\begin{tabular}{|c|c|c|c|c|c|c|c|}
\hline \multirow[t]{3}{*}{ Characteristic } & \multirow[t]{3}{*}{ Factor } & & \multirow{2}{*}{$\begin{array}{l}\text { Categories } \\
\text { Employed }\end{array}$} & \multirow[b]{2}{*}{ Unemployed } & \multirow[b]{2}{*}{ Student } & \multirow[t]{2}{*}{$F$ value } & \multirow[t]{2}{*}{$p$-Val } \\
\hline & & & & & & & \\
\hline & & $N$ & 171 & 53 & 161 & 2.19 & .113 \\
\hline \multirow[t]{2}{*}{$\begin{array}{l}\text { Impact Mental } \\
\text { Health }\end{array}$} & $\begin{array}{l}\text { Employ } \\
\text { ment }\end{array}$ & Mean & 30.94 & 30.98 & 30.24 & & \\
\hline & & S.D. & 3.12 & 3.11 & 3.44 & & \\
\hline
\end{tabular}

$* p \leq 0.05$.

**The mean difference is significant at the .05 level.

Table 6 shows the result of ANOVA between the location groups and the mental health impact of the respondents. Tukey's post hoc test was conducted to assess which location group, City, Town and Sub-urban, had shown the significant difference. The analysis shows no significant difference between the three location groups and mental health impact ( $p>0.05)$. Therefore, there is no difference in the impact on young women's mental state caused by street harassment such as anxiety, low self-esteem or depression based on their location. Street harassment among young women can happen anywhere, such as the city, town or suburban.

Table 7. Location Group Factor

\begin{tabular}{|c|c|c|c|c|c|c|c|}
\hline \multirow[t]{3}{*}{ Characteristic } & \multirow[t]{3}{*}{ Factor } & & \multicolumn{3}{|c|}{ Categories } & \multirow[t]{2}{*}{$F$ value } & \multirow[t]{2}{*}{$p$-Value } \\
\hline & & & City & Town & Sub-urban & & \\
\hline & & $N$ & 83 & 53 & 116 & 1.30 & .274 \\
\hline \multirow[t]{2}{*}{$\begin{array}{l}\text { Impact } \\
\text { Mental Health }\end{array}$} & Location & $\begin{array}{l}\text { Mea } \\
n\end{array}$ & 30.38 & 30.96 & 0.87 & & \\
\hline & & S.D. & 3.53 & 2.74 & 3.17 & & \\
\hline
\end{tabular}

$* p \leq 0.05$.

**The mean difference is significant at the .05 level.

\section{Conclusion}

This present study revealed that most young Malaysian women in Klang Valley mostly experienced street harassment, which affected their mental health in different ways. However, the severity of Young Malaysian women's mental health due to their experience of street harassment may have other contributing factors that influence the mental health conditions based on all the socio-demographic factors tested in this study; age, race, employment status and location. The different significant values of all the socio-demographic factors tested in the current study enable the future researcher to look at other aspects or factors such as the types of mental health women face when they experience street harassment. The severity level of types of harassment must also need to be investigated further as the acceptance level of people of different cultures may show different impacts on mental health among women who experience street harassment. This study was only 
conducted in the Klang Valley area due to the highest sexual harassment cases and did not represent the whole population. Its sampling method would also limit the findings' ability for generalization, and this study's scope only examined one aspect of street harassment, which addresses the street harassment experience only. This study will contribute to developing strategic mechanisms among the medical practitioner and psychologist to understand and handle the cases of street harassment among young Malaysian women.

\section{References}

Betts, L., Harding, R., Peart, S., Sjolin Knight, C., Wright, D., \& Newbold, K. (2019). Adolescents' experiences of street harassment: Creating a typology and assessing the emotional impact. Journal of Aggression, Conflict and Peace Research, 11(1), 38-46. https://doi.org/10.1108/JACPR-12-2017-0336

Chafai, H. (2017). Contextualising street sexual harassment in Morocco: A discriminatory sociocultural representation of women. Journal of North African Studies, 22(5), 821840. https://doi.org/10.1080/13629387.2017.1364633

Dandavati, N. (2020). Women's Experiences and Perceptions of Sexual Harassment Demonstrate the Urgent Need for a Sexual Harassment Act - Women's Aid Organisation. https://wao.org.my/womens-experiences-and-perceptions-of-sexual-harassmentdemonstrate-the-urgent-need-for-a-sexual-harassment-act/

Dandavati, N. (2020). JAG welcomes the announcement that the Sexual Harassment Bill will be tabled and urges the government to continue engagement to ensure survivors benefit - Women's Aid Organisation. https://wao.org.my/jag-welcomes-the-announcementthat-the-sexual-harassment-bill-will-be-tabled-and-urges-the-government-tocontinue-engagement-to-ensure-survivors-benefit/

Davidson, M. M., Butchko, M. S., Robbins, K., Sherd, L. W., \& Gervais, S. J. (2016). The Mediating Role of Perceived Safety on Street Harassment and Anxiety. Psychology of Violence, 6(4), 553-561. https://doi.org/10.1037/A0039970

DelGreco, M., \& Christensen, J. (2020). Effects of Street Harassment on Anxiety, Depression, and Sleep Quality of College Women. Sex Roles, 82(7-8), 473-481. https://doi.org/10.1007/S11199-019-01064-6

Dhillon, M., \& Bakaya, S. (2014). Street Harassment a Qualitative Study of the Experiences of Young Women in Delhi, $1-2$. https://scihub. se/https://journals.sagepub.com/doi/10.1177/2158244014543786

Farmer, O., \& Jordan, S. (2017). Experiences of Women Coping With Catcalling Experiences in New York City: A Pilot Study. Journal of Feminist Family Therapy, 29(4), 205-225. https://doi.org/10.1080/08952833.2017.1373577

Fileborn, B., \& Vera-Gray, F. (2017). "I Want to be Able to Walk the Street Without Fear": Transforming Justice for Street Harassment. Feminist Legal Studies, 25(2), 203-227. https://doi.org/10.1007/S10691-017-9350-3

Gavin, M., \& Mp, S. (2018). Sexual harassment of women and girls in public places Sixth Report of Session 2017-19 Report, together with formal minutes relating to the report. www.parliament.uk.

Penfield, C. (2017). Sexual Harassment at School. In Executive Educator, 15(2). https://search.proquest.com/docview/62874735?accountid $=13042 \%$

OAhttp://oxfordsfx.hosted.exlibrisgroup.com/oxford?url_ver=Z39.88- 
2004\&rft_val_fmt=info:ofi/fmt:kev:mtx:journal\&genre=article\&sid=ProQ:ProQ\%3Aeri c\&atitle $=$ Sexual+Harassment+at+School\&title=Execut

Renwick, R., Yoshida, K., Eacrett, E., \& Rose, N. (2016). Meaning of Staring and the Stare Relationship Related to Men Living with Acquired Spinal Cord Injuries, 1-4. https://scihub.se/https://www.researchgate.net/publication/ 294424264_Meaning_of_Staring_and_the_StarerStaree_Relationship_Related_ to_Men_Living_With_Acquired_Spinal_Cord_Injuries

Safe Routes to School National Partnership. (2017). How Safe Routes to School Programs Can Take Action to Protect Kids from Street Harassment: Wolf Whistles and Creepy Compliments. https://core.ac.uk/display/86445439.

Stop Street Harassment. (2015). What is street harassment? http://www.stopstreetharassment.org/about/what-is-street-harassment/ Sexual Harassment Statistics in Malaysia - Women's Aid Organisation. (n.d.). https://wao.org.my/sexual-harassment-statistics/

Vera-Gray, F. (2016). Men's stranger intrusions: Rethinking street harassment. Women's Studies International Forum, 58, 9-17. https://doi.org/10.1016/J.WSIF.2016.04.001

Westrupa, D., \& William, J. F. (1998) Stalking behavior: A literature review and suggested functional analytic assessment technology. https://www.sciencedirect.com/ science/article/abs/pii/S1359178997000232

Chung, Y. R. (2020). Survey supports calls to Make Stalking A Crime in Malaysia. https://wao.org.my/wp-content/uploads/2020/12/Survey-supports-calls-to-Make Stalking-A-Crime-in-Malaysia-WAO-Presentation.pdf 